\title{
Investigation of Optoelectronic Properties of Organic Semiconductor Tetracyaoquinodimethane Based Heterostructures
}

\author{
Burcu AVCI ${ }^{1}$, Ali Akbar HUSSAINI ${ }^{2}$, Mehmet Okan ERDAL ${ }^{3}$, Murat YILDIRIM ${ }^{4 *}$ \\ *Corresponding Auhor: muratyildirim@selcuk.edu.tr \\ ${ }^{1}$ Selcuk University, Faculty of Science, Department of Biotechnology, KONYA \\ Orcid No: 0000-0003-4455-5684 / burcuyalcin16@gmail.com \\ 2 Selcuk University, Faculty of Science, Department of Biotechnology, KONYA \\ Orcid No: 0000-0002-7128-9994 / aliakbar.hussaini.1994@gmail.com \\ ${ }^{3}$ Necmettin Erbakan University, Meram Vocational School, 42090, KONYA \\ Orcid No: 0000-0003-4469-3438 / moerdal@erbakan.edu.tr \\ ${ }^{4}$ Selcuk University, Faculty of Science, Department of Biotechnology, KONYA \\ Orcid No: 0000-0002-4541-3752 / muratyildirim@selcuk.edu.tr
}

\begin{abstract}
Recently, interfacial layer such as metal oxide, insulator and polymer have been used by scientists between the metal and semiconductor to increase the stability of the metal-semiconductor heterojunctions. These materials have been varied according to their usage aims. In this study, graphene nanoribbons (GNR) and 7,7,8,8 Tetracyanoquinodimethane (TCNQ, $\mathrm{C}_{12} \mathrm{H}_{4} \mathrm{~N}_{4}$ ) layer has been used as interfacial layer between the metal and semiconductor for photodiode applications. The TCNQ layer collects and extracts more electrons in the interface of the device and is used as electron acceptor material for organic solar cells. Herein, we fabricated $\mathrm{Al} / p-\mathrm{Si} / \mathrm{Al}$, $\mathrm{Al} / p$-Si/TCNQ/Al and Al/p-Si/TCNQ:GNR/Al heterojunctions by physical vapor deposition technique. $I-V$ measurements has been employed under dark and various light illumination conditions to show dielectric properties of the fabricated heterojunctions. From current-voltage characteristics, we calculated the electronic parameters such as ideality factor, barrier heights, series resistances and rise times. It can be concluded from overall results that TCNQ and TCNQ:GNR layers had a major impact on quality and can be considered as quite proper materials for optoelectronic applications.
\end{abstract}

Keywords: Al/p-Si/TCNQ:GNR/Al, Heterostructure, Optoelectronic, Photodiode

\section{Organik Yariiletken Tetrasiyaokuinodimetan Tabanlı Heteroyapıların Optoelektronik Özelliklerinin Araştırılması}

Öz: Son yıllarda bilim insanları metal-yariiletken heteroeklemlerinin dayanıklılığını arttırmak maksadıyla metal ile yariiletken arasına metal oksit, yalıtkan veya da polimer tabakalar eklemektedirler. Bu malzemeler amaca göre değişiklik göstermektedir. Bu çalışma kapsamında, fotodiyot uygulamaları için metal ve yarı iletken arasında ara yüzey olarak grafen nanoribbon (GNR) ve 7,7,8,8 Tetrasiyaokuinodimetan(Tetracyanoquinodimethane TCNQ, $\mathrm{C}_{12} \mathrm{H}_{4} \mathrm{~N}_{4}$ ) katmanı kullanılmıştır. TCNQ katmanı, cihazın arayüzünde daha fazla elektron toplar ve çıkarır ve organik güneş pillerinde elektron alıcı malzeme olarak kullanılır. Daha sonra fiziksel buhar biriktirme yöntemiyle $\mathrm{Al} / p$-Si/Al, Al/p-Si/TCNQ/Al ve Al/p-Si/TCNQ:GNR/Al heteroeklemleri elde edilmiştir. Elektriksel karakterizasyon kapsamında Akım-voltaj ölçümleri hem karanlık ortamda hemde farklı aydınlatma değerlerinde gerçekleştirilmiştir. Akım-voltaj karakteristiklerinden, idealite faktörü, bariyer yüksekliği, seri direnç ve yükselme zamanı gibi elektronik parametreler hesaplanmıştır. Sonuç olarak, TCNQ ve TCNQ:GNR katmanlarının kalite üzerinde büyük bir etkisi olduğu ve optoelektronik uygulamalar için oldukça uygun malzemeler olarak kabul edilebilebilir.

Anahtar Kelimeler: Al/p-Si/TCNQ:GNR/Al, Heteroeklem, Optoelektonik, Fotodiyot 


\section{Introduction}

Metal-Semiconductor (MS) contacts are called Schotkky diodes after its inventor W. Schottky (Wager et al., 2008). Schottky barrier diodes (SBDs) are metalsemiconductor (MS) contacts that are extensively used in semiconductor manufacturing (Berk et al., 2021), temperature-sensing (Zeghdar et al., 2020) and solar cells applications (Ramadan \& Martín-Palma, 2020). On the other hand, metal-semiconductor heterojunctions have a wide range of usages in solar cells, rectifiers, capacitors, photodetectors and transistors fabrications (Munikrishana Reddy et al., 2013).

SBDs have shown high electric field and breakdown voltages (Rouger \& Maréchal, 2019). In addition, Schottky diodes have very high switching speed and temperature stability compared to $p-n$ junction diode (Kyoung et al., 2016). Because the operation of Schottky diodes is based on carriers (Anthopoulos et al., 2006). If the interface layer thickness (di) between metal and semiconductor increases above a few hundred Angstroms $(\AA)$, then these structures are termed as metal/insulatoroxide-polymer/semiconductor (MIS, MOS, MPS) diodes rather than Schottky diodes (Gökçen et al., 2012; Yücedag et al., 2014). In recent years, polymer interface materials have been used to increase the properties of these devices (Srivastava \& Chakrabarti, 2015; Tozlu \& Mutlu, 2016).

There has been rising amount of researchs to enhance the electrical properties of diodes by inserting organics (Erdal et al., 2021; Eroğlu et al., 2020; Meftah et al., 2020), metal oxides (Yenel et al., 2021) and nanocrystals materials (Kocyiğit et al., 2021; Koçyiğit et al., 2021; Yıldırım et al., 2020). Recently, graphene (Gr) has attracted numerous attention due to its properties in optoelectronic devices. Moreover, graphene nanoribbons (GNR) seems to be advantageous than graphene due its band gap, and applicable in diodes and transistors manufacture (Sato, 2017).

Ye et al. (2011) have reported the first synthesis of GNR doped heterojunction using as light-emitting diodes (LEDs). The obtained device can emit light with $380 \mathrm{~nm}$, $523 \mathrm{~nm}$ and $705 \mathrm{~nm}$ wavelengths. Furthermore, Shamsir et al. (2021) have also modified p-n junction diode based on GNR. In another research, Erdal et al. (2019) have used GNR and MWCNT layers on $p$-Si successfully which can be applied in various industries potentially. Double gate GNR diode compesed by Kargar and Lee (2009), have shown $\sim 2 \times 10^{7}$ rectification ratio at 0.2 V bias voltage. Rahmani et al. (2013) have explored application of bilayer GNR doped SBDs. Tataroğlu et al. (2021) have fabricated graphene-PVP/Au/ $n-\mathrm{Si}$ diode via spin-coating. Gr-PVP addition to the 
obtained device have shown incredible performance which can be applied instead of the insulator layer. In another study, Wang et al. (2020) have coated graphene oxide (GO) on graphene-silicon heterojunction. GO in obtained photodetector device have exhibited great effects by suppressing the dark current and increasing the photocurrent 2.73 times and responsivity to $0.65 \mathrm{~A} / \mathrm{W}$ under $633 \mathrm{~nm}$ illumination. Moreover, Orhan et al. (2020) have synthesized CuOGraphene/ $p$-Si device by spin-coating and investigated the impact of gamma irradiation on it. In another research by Karadaş et al. (2021) $1 \%, 3 \%, 5 \%, 7 \%$, and $10 \%$ graphene have been doped in PVA then coated on $n$ Si. Among them, 7\% Gr doped-PVA interlayer have demonstrated best rectifying rate, with low series resistance.

Many Schottky diodes are prepared and characterized using metals, inorganic semiconductors and organic conductive polymers. The electrical and photoelectric properties of polymeric and non-polymeric organic compounds are widely investigated. It was found that the heterostructures containing non-polymeric and polymeric organic thin films have considerable rectifying properties. $\mathrm{Al} / \mathrm{PVC}-$ TCNQ:ZnO/p-Si device synthesized by Erdal et al. (2021) demonstrated a linear photoconductivity, and photoresponsivity of the obtained device has been improved by $\mathrm{ZnO}$ doping significantly. In another study,
Taşçığlu et al. (2017) have fabricated Au/P3HT:PCBM:F4-TCNQ/n-Si Schottky barrier diode (SBDs) via spin-coating and investigated electrical and dielectric properties between $10 \mathrm{kHz}-2 \mathrm{MHz}$. Çimen et al. (2018) have investigated the concentration of TCNQ on Au/P3HT:F4TCNQ $/ n-\mathrm{Si}$ on SBDs which improves the quality of devices. Moreover, Mun et al. (2020) have successfully fabricated F4TCNQ doped stretchable semiconductor showing high mobility and stability.

Within the scope of this study, $\mathrm{Al} / p$ $\mathrm{Si} / \mathrm{Al}, \quad \mathrm{Al} / p-\mathrm{Si} / \mathrm{TCNQ} / \mathrm{Al} \quad$ and $\mathrm{Al} / p-$ $\mathrm{Si} / \mathrm{TCNQ}: \mathrm{GNR} / \mathrm{Al}$ heterojunctions have been fabricated successfully. The effects of TCNQ and TCNQ:GNR layers to the interlayer of the metal-semiconductor heterojunction structure have been investigated. The devices have been characterized by taking temperaturedependent $I-V$ measurements for determinition of dielectric constants. The aim of the project is basically to obtain the TCNQ:GNR heterojunction structure and to determine the photosensitivity properties depending on the illumination intensity.

\section{Material and Method}

The $p$-type Si wafer used as substrate was cut to $1.5 \mathrm{~cm}^{2}$ pieces, then they were cleaned by $\mathrm{H}_{2} \mathrm{O}_{2}: \mathrm{H}_{2} \mathrm{O}: \mathrm{HCl}$, $\mathrm{H}_{2} \mathrm{O}_{2}: \mathrm{H}_{2} \mathrm{O}: \mathrm{NH}_{4} \mathrm{OH}$, isopropanol and acetone solutions in an ultrasonic bath and dried by 
nitrogen subsequently. Moreover, in order to remove impurities, $\mathrm{Si}$ pieces were steeped into $\mathrm{HF}: \mathrm{H}_{2} \mathrm{O} \quad(1: 1)$ solution. The wafer owned perfect crystalline orientation and $7.5 \times 10^{16} \mathrm{~cm}^{-3}$ carrier concentration.

Ohmic contact was created on the back surface of the Si pieces by evaporating pure $\mathrm{Al}(99.999 \%)$ at $8 \times 10^{-6}$ torr pressure in PVD. Si substrates with $150 \mathrm{~nm}$ thickness of $\mathrm{Al}$ achieved in PVD was dealed with 450 ${ }^{\circ} \mathrm{C}$ temperature for 3 minutes. TCNQ and TCNQ:GNR solutions were coated on $\mathrm{Si}$ wafer via spin-coating. Spin-coating has been performed in $1500 \mathrm{rpm}$ for $45 \mathrm{~s}$ using Fytronix SC-500 spin coater. After coating, doped and undoped Si substrates were put into PVD for Al evaporation via hole array mask. The hole radius was determined as $7.85 \times 10^{-3} \mathrm{~cm}^{2}$. The hole radius was determined as $7.85 \times 10^{-3} \mathrm{~cm}^{2}$ and $150 \mathrm{~nm}$ of thickness. This evaporation was created in same pressure. Obtained heterostructures were analyzed via Fytronix FY-7000 Electronic Device characterization system for the $I-V$ and $I-T$ measurements. The measurement temperatures were changed between $50-400 \mathrm{~K}$ by $50 \mathrm{~K}$ steps. Schematic diagrams of fabricated heterojunctions are given in Figure 1.

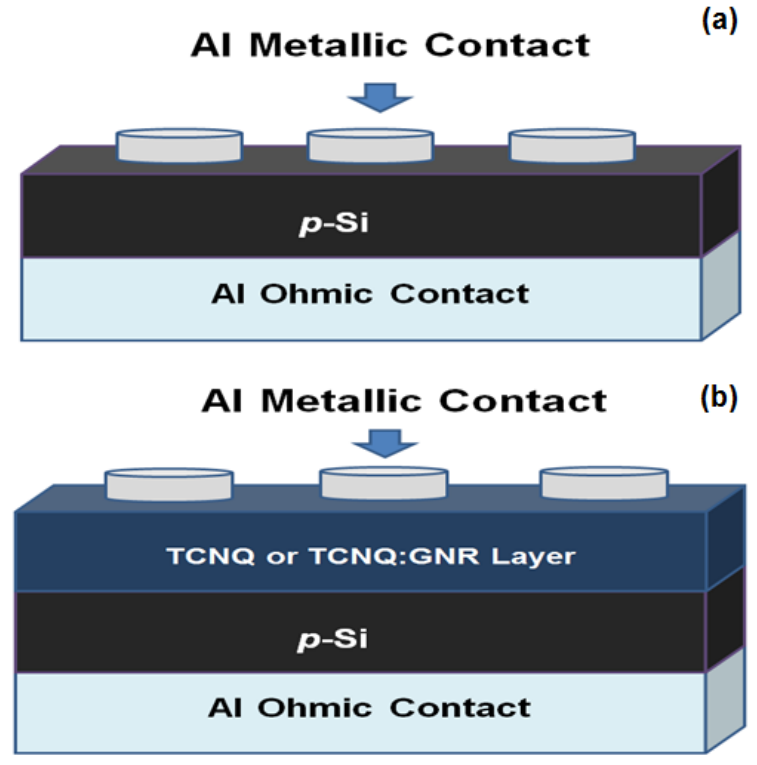

Figure 1. Schematic diagrams of (a) $\mathrm{Al} / p-\mathrm{Si} / \mathrm{Al}$ and (b) $\mathrm{Al} / p-\mathrm{Si} / \mathrm{TCNQ} / \mathrm{Al}$ or $\mathrm{Al} / p-\mathrm{Si} / \mathrm{TCNQ}: \mathrm{GNR} / \mathrm{Al}$ heterostructures.

\section{Result and Discussion}

\subsection{Electrical characteristics of the}

\section{fabricated photodiodes}

$I-V$ characteristics of the $\mathrm{Al} / p-\mathrm{Si} / \mathrm{Al}, \mathrm{Al} / p$ $\mathrm{Si} / \mathrm{TCNQ} / \mathrm{Al}$ and Al/p-Si/TCNQ:GNR/Al heterostructures have been shown in Fig. 2 under various light power intensities. $\mathrm{Al} / p$ $\mathrm{Si} / \mathrm{TCNQ} / \mathrm{Al}$ and Al/p-Si/TCNQ:GNR/Al devices exhibited increasing current profile in the forward bias region with increasing light power intensity. Furthermore, $\mathrm{Al} / p$ $\mathrm{Si} / \mathrm{TCNQ} / \mathrm{Al}$ and Al/p-Si/TCNQ:GNR/Al heterostructures can be considered as twolead phototransistors. In as much as, they have been exhibiting a phototransistor behavior and increasing base current with increasing light power intensity and staying constant with increasing voltage in the forward bias region. The phototransistors usually can be grown on the $\mathrm{SiO}_{2} / \mathrm{Si}$ surface 
as FET structure or PNP structure as BJT on a one substrate and they are illuminated for switching (Kim et al., 2017; Kostov et al., 2013; Shao et al., 2019; Xie et al., 2020). In this study, we used normal Schottky type photodetector with n-type TCNQ and TCNQ:GNR interlayers. The $n$-type TCNQ and TCNQ:GNR layers can absorb the light and emit electrons to the medium significantly. While the photodiodes or photodetectors work in the reverse biases, the phototransistors run in the forward bias region. We have both photodiode behavior in reverse biases and phototransistor behavior in the forward bias region. The threshold values of the fabricated device were calculated from these graphs and discussed broadly.
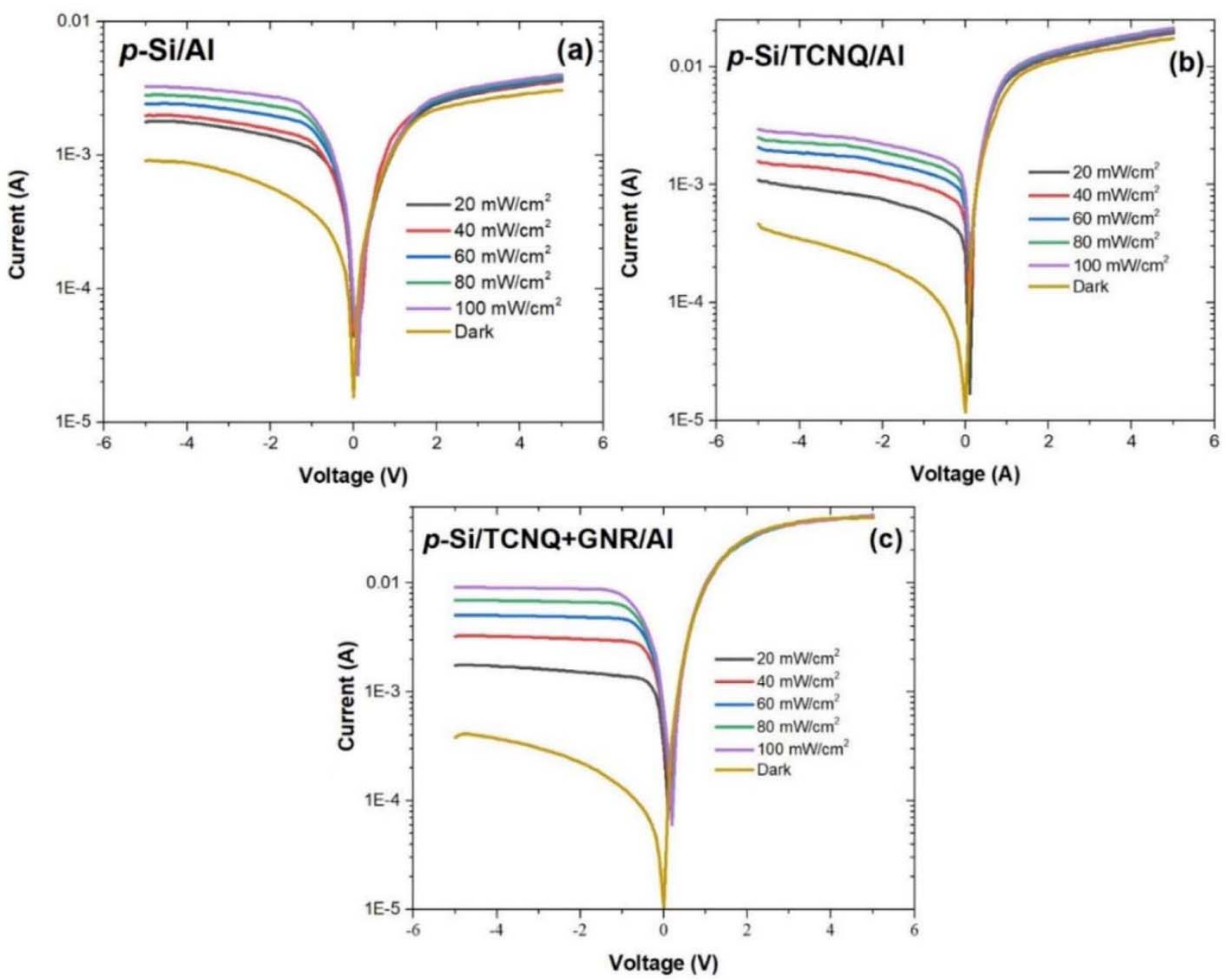

Figure 2. $\ln I-V$ plots of the (a) $\mathrm{Al} / p-\mathrm{Si} / \mathrm{Al}$, (b) $\mathrm{Al} / p-\mathrm{Si} / \mathrm{TCNQ} / \mathrm{Al}$ and (c) $\mathrm{Al} / p-\mathrm{Si} / \mathrm{TCNQ}: \mathrm{GNR} / \mathrm{Al}$ heterostructures.

$\ln I-V$ plots are used generally to calculate ideality factor, barrier height and series resistance of the metal semiconductor devices by thermionic emission theory, Norde and Cheung methods (Kocyigit et al.,
2019). According to thermionic emission theory, while the slope of the second region at the forward bias $\ln I-V$ plot provides to calculate the ideality factor, y-intercept of the plot helps calculate barrier height value 
(Tataroğlu et al., 2021). Fig. 2(a), 2(b) and 2(c) show the $\ln I-V$ plots of the $\mathrm{Al} / p-\mathrm{Si} / \mathrm{Al}$, $\mathrm{Al} / p-\mathrm{Si} / \mathrm{TCNQ} / \mathrm{Al} \quad$ and $\quad \mathrm{Al} / p$ Si/TCNQ:GNR/Al heterostructures under dark and $100 \mathrm{~mW} / \mathrm{cm}^{2}$ light power intensity, respectively. The changes of the current in the reverse bias regions can clearly be seen in given graphs. Obtained devices exhibited increasing photocurrent profile in the reverse bias as well as forward bias regions. This result demonstrates the photodiode behavior of the fabricated devices with phototransistor behaviors (Özmen et al., 2019).

The ideality factor, saturation current and barrier height values were calculated and listed in Table 1 according to thermionic emission theory for dark condition. The ideality factor values of the $\mathrm{Al} / p-\mathrm{Si} / \mathrm{Al}$, $\mathrm{Al} / p-\mathrm{Si} / \mathrm{TCNQ} / \mathrm{Al} \quad$ and $\mathrm{Al} / p$ Si/TCNQ:GNR/Al heterostructures were determined as 2.56, 2.07 and 2.20, and the barrier height values were calculated as 3.76 $\mathrm{eV}, 1.99 \mathrm{eV}$ and $2.45 \mathrm{eV}$, respectively. The high ideality factor values at the $\mathrm{Al} / p$ $\mathrm{Si} / \mathrm{TCNQ} / \mathrm{Al}$ and Al/p-Si/TCNQ:GNR/Al devices can be attributed to barrier inhomogeneity and interfacial TCNQ and TCNQ:GNR layers as well as series resistance rather than more than unity (Cifci et al., 2018; Kacus et al., 2020). Current transient (I- $t$ ) measurements of the $\mathrm{Al} / p$ $\mathrm{Si} / \mathrm{Al}, \quad \mathrm{Al} / p-\mathrm{Si} / \mathrm{TCNQ} / \mathrm{Al}$ and $\mathrm{Al} / p-$ Si/TCNQ:GNR/Al devices have been shown in Fig. 3(a), 3(b) and 3(c), respectively. The currents of the fabricated devices suddenly increased when the light is applied for all various light power intensity values, and decreased immediately when it is off. This result accentuated that the fabricated devices have good responsivity to the light illumination (İlhan et al., 2021). Moreover, the current increased almost linearly on the all devices with increasing light power intensity and maximum current was obtained for $100 \mathrm{~mW} / \mathrm{cm}^{2}$ values. The rise times of the devices were obtained as 45.08 $\mathrm{ms}, 46.12 \mathrm{~ms}$ and $46.55 \mathrm{~ms}$ for the $\mathrm{Al} / p$ $\mathrm{Si} / \mathrm{Al}, \quad \mathrm{Al} / p-\mathrm{Si} / \mathrm{TCNQ} / \mathrm{Al} \quad$ and $\mathrm{Al} / p-$ Si/TCNQ:GNR/Al devices, respectively. These results can be indicated to good response time according to literature $(\mathrm{Hu}$ et al., 2021).

Table 1. Various diode parameters for the $\mathrm{Al} / p$-Si/Al, $\mathrm{Al} / p-\mathrm{Si} / \mathrm{TCNQ} / \mathrm{Al}$ and $\mathrm{Al} / p-\mathrm{Si} / \mathrm{TCNQ}: \mathrm{GNR} / \mathrm{Al}$ heterostructures.

\begin{tabular}{|c|c|c|c|c|c|c|}
\hline $\begin{array}{c}\text { Interface } \\
\text { Type }\end{array}$ & $\begin{array}{c}n \\
(I-V)\end{array}$ & $\begin{array}{c}n \\
\text { Cheung }\end{array}$ & $\begin{array}{c}\Phi_{b} \\
(I-V) \\
(\mathrm{eV})\end{array}$ & $\begin{array}{c}\Phi_{b} \\
\text { Cheung } \\
(\mathrm{eV})\end{array}$ & $\begin{array}{c}\boldsymbol{R}_{s} \\
\text { Cheung } \\
(\Omega(H(I))\end{array}$ & $\begin{array}{c}\mathbf{R}_{s} \\
\text { Cheung } \\
(\Omega(d)(I)))\end{array}$ \\
\hline Undoped & 2.56 & 3.76 & 0.68 & 0.56 & 180 & 203 \\
\hline TCNQ & 2.07 & 1.99 & 0.82 & 0.77 & 2950 & 1345 \\
\hline TCNQ:GNR & 2.20 & 2.45 & 0.75 & 0.61 & 2260 & 1012 \\
\hline
\end{tabular}



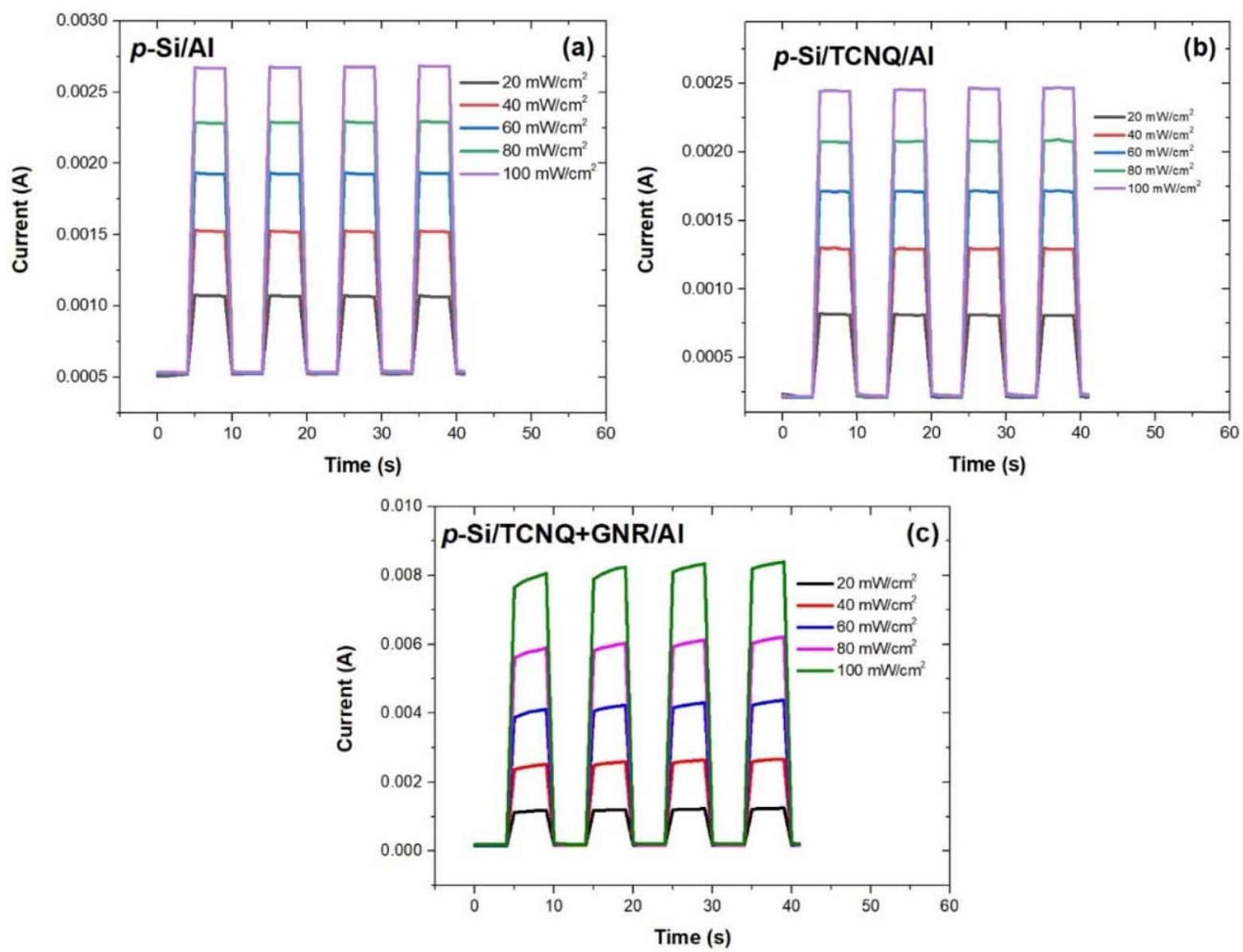

Figure 3. I- $t$ graphs of the (a) $\mathrm{Al} / p-\mathrm{Si} / \mathrm{Al}$, (b) $\mathrm{Al} / p-\mathrm{Si} / \mathrm{TCNQ} / \mathrm{Al}$ and (c) $\mathrm{Al} / p-\mathrm{Si} / \mathrm{TCNQ}: \mathrm{GNR} / \mathrm{Al}$ heterostructures.

Current transient $(I-t)$ measurements of the $\mathrm{Al} / p-\mathrm{Si} / \mathrm{Al}, \mathrm{Al} / p-\mathrm{Si} / \mathrm{TCNQ} / \mathrm{Al}$ and $\mathrm{Al} / p$-Si/TCNQ:GNR/Al devices have been shown in Fig. 3(a), 3(b) and 3(c), respectively. The currents of the fabricated devices suddenly increased when the light is applied for all various light power intensity values, and decreased immediately when it is off. This result accentuated that the fabricated devices have good responsivity to the light illumination (İlhan et al., 2021). Moreover, the current increased almost linearly on the all devices with increasing light power intensity and maximum current was obtained for $100 \mathrm{~mW} / \mathrm{cm}^{2}$ values. The rise times of the devices were obtained as $45.08 \mathrm{~ms}, 46.12 \mathrm{~ms}$ and $46.55 \mathrm{~ms}$ for the $\mathrm{Al} / p-\mathrm{Si} / \mathrm{Al}, \quad \mathrm{Al} / p-\mathrm{Si} / \mathrm{TCNQ} / \mathrm{Al}$ and $\mathrm{Al} / p$ Si/TCNQ:GNR/Al devices, respectively. These results can be indicated to good response time according to literature ( $\mathrm{Hu}$ et al., 2021).

\section{Conclusion}

TCNQ and TCNQ:GNR layers on $p$ Si substrate have been fabricated successfully. The electrical characterization of the devices was performed by $I-V$ measurements under dark and various light power intensities. From current-voltage 
characteristics, the electronic parameters such as ideality factors, barrier heights, series resistances and rise times were calculated. The fabricated devices exhibited considerable responsivity and specific detectivity. It can be concluded from overall results that TCNQ and TCNQ:GNR layers had a major impact on quality and can be considered as quite proper materials for optoelectronic applications.

\section{Acknowledgements}

This work is a part of the M.Sc. thesis preparing by B. Avc1. This work is supported by Selcuk University BAP office with the research project number 20211024.

\section{References}

Anthopoulos, TD, Singh B, Marjanovic N, Sariciftci NS, Montaigne Ramil A., Sitter H, Cölle M., De Leeuw DM (2006). High performance n -channel organic field-effect transistors and ring oscillators based on C60 fullerene films. Applied Physics Letters 89(21): 7-10.

Berk N, Seymen H, Orak I, Karataş Ş (2021). The electrical characteristics of metalsemiconductor hetero-structures with graphene oxide and perylenetetracarboxylic dianhydride interface. Journal of Materials Science: Materials in Electronics 32(13): $17500-17511$.

Cifci OS, Bakir M, Meyer JL, Kocyigit A (2018). Morphological and electrical properties of ATSP/p-Si photodiode. Materials Science in Semiconductor Processing 74: 175-182.

Çimen A, Şağban HM, Özdemir T, Özmen ÖT (2018). F4-TCNQ Concentration dependent capacitance-voltage $(\mathrm{C}-\mathrm{V})$ and conductivity-voltage $(\mathrm{G} / \mathrm{w}-\mathrm{V})$ characteristics of the $\mathrm{Au} / \mathrm{P} 3 \mathrm{HT}: \mathrm{F} 4-\mathrm{TCNQ} / \mathrm{N}-\mathrm{Si}$ (MPS) schottky barrier diodes. "International Journal of Engineering Science Invention, 7(July), 17-25.

Erdal, MO, Koyuncu M, Doğan K, Öztürk T, Kocyigit A, Yıldırım M (2021). The modification of the characteristics of $\mathrm{ZnO}$ nanofibers by TCNQ doping content. Journal of Materials Science: Materials in Electronics 32(13) 17220-17229.

Erdal MO, Y1ldirım M, Kocyigit A (2019). A comparison of the electrical characteristics of $\mathrm{TiO} 2 / \mathrm{p}-\mathrm{Si} / \mathrm{Ag}, \mathrm{GNR}-\mathrm{TiO} 2 / \mathrm{p}-\mathrm{Si} / \mathrm{Ag}$ and MWCNT-TiO2/p-Si/Ag photodiodes. Journal of Materials Science: Materials in Electronics 30(14): 13617-13626.

Eroğlu A, Demirezen S, Azizian-Kalandaragh Y, Altındal Ş (2020). A comparative study on the electrical properties and conduction mechanisms of $\mathrm{Au} / \mathrm{n}-\mathrm{Si}$ Schottky diodes with/without an organic interlayer. Journal of Materials Science: Materials in Electronics 31(17): 14466-14477.

Gökçen M, Altuntaş H, Altndal Ş, Özçelik S (2012). Frequency and voltage dependence of negative capacitance in $\mathrm{Au} / \mathrm{SiO} 2 / \mathrm{n}-\mathrm{GaAs}$ structures. Materials Science in Semiconductor Processing 15(1): 41-46.

Hu X, Li X, Li G, Ji T, Ai F, Wu J, Ha E, Hu J (2021). Recent progress of methods to enhance photovoltaic effect for self-powered heterojunction photodetectors and their applications in inorganic low-dimensional structures. In Advanced Functional Materials (p. 2011284). John Wiley and Sons Inc. 
İlhan M, Koç MM, Coşkun B, Erkovan M, Yakuphanoğlu F (2021). Cd dopant effect on structural and optoelectronic properties of $\mathrm{TiO}_{2}$ solar detectors. Journal of Materials Science: Materials in Electronics 32(2): 2346-2365.

Kacus H, Sahin Y, Aydogan S, Incekara U, Yilmaz M (2020). Co/aniline blue/silicon sandwich hybrid heterojunction for photodiode and low-temperature applications. Journal of Sandwich Structures \& Materials 109963622090994.

Karadaş S, Yerişkin SA, Balbaşı M, Azizian-Kalandaragh Y (2021). Complex dielectric, complex electric modulus, and electrical conductivity in $\mathrm{Al} /(\mathrm{Graphene}-\mathrm{PVA}) / \mathrm{p}-\mathrm{Si}$ (metal-polymer-semiconductor) structures. Journal of Physics and Chemistry of Solids 148(February 2020).

Kargar A, Lee C (2009). Graphene nanoribbon schottky diodes using asymmetric contacts. 2009 9th IEEE Conference on Nanotechnology, IEEE NANO 2009, 8: 243-245.

Kim MS, Lee GJ, Kim HM, Song YM (2017). Parametric optimization of lateral NIPIN phototransistors for flexible image sensors. Sensors (Switzerland) 17(8): 1774.

Koçyiğit A, Erdal MO, Ozel F, Yıldırım M (2021). Photodiode behaviors of the AgSbS 2 nanocrystals in a Schottky structure. Nanotechnology 32(38): 385204.

Kocyiğit A, Sarilmaz A, Öztürk T, Ozel F, Murat Y (2021). The Au/CuNiCoS4/p -Si photodiode : Electrical and Morphological Characterization 0-25.

Kocyigit A, Y1ldırım M, Sarılmaz A, Ozel F (2019). The Au/Cu2WSe4/p-Si photodiode: Electrical and morphological characterization. Journal of Alloys and Compounds 780: 186-192.

Kostov P, Gaberl W, Zimmermann H (2013). High-speed bipolar phototransistors in a $180 \mathrm{~nm}$ CMOS process. Optics and Laser Technology 46(1): 6-13.

Kyoung S, Jung ES, Sung MY (2016). Post-annealing processes to improve inhomogeneity of Schottky barrier height in Ti/Al 4H-SiC Schottky barrier diode. Microelectronic Engineering 154: 69-73.

Meftah SE, Benhaliliba M, Kaleli M, Benouis CE, Yavru CA, Bayram AB (2020). Optical and electrical characterization of thin film MSP heterojunction based on organic material Al/p-Si/P3HT/Ag. Physica B: Condensed Matter 593(April), 412238.

Mun J, Kang J, Zheng Y, Luo S, Wu Y, Gong H, Lai JC, Wu HC, Xue G, Tok JBH, Bao Z (2020). F4-TCNQ as an additive to impart stretchable semiconductors with high mobility and stability. Advanced Electronic Materials 6(6): 1-9.

Munikrishana Reddy Y, Nagaraj MK, Siva Pratap Reddy M, Lee JH, Rajagopal Reddy V (2013). Temperature-dependent current-voltage (I-V) and capacitance-voltage (C-V) characteristics of $\mathrm{Ni} / \mathrm{Cu} / \mathrm{n}-\mathrm{InP}$ schottky barrier diodes. Brazilian Journal of Physics 43(1-2): 13-21.

Orhan Z, Cinan E, Çaldıran Z, Kurucu Y, Daş E (2020). Synthesis of CuO-graphene nanocomposite material and the effect of gamma radiation on $\mathrm{CuO}$-graphene/p-Si junction diode. Journal of Materials Science: Materials in Electronics 31(15): 1271512724.

Özmen A, Aydogan S, Yilmaz M. (2019). Fabrication of spray derived nanostructured n$\mathrm{ZnO} / \mathrm{p}-\mathrm{Si}$ heterojunction diode and investigation of its response to dark and light. Ceramics International. 
Rahmani M, Ismail R, Ahmadi MT, Kiani MJ, Saeidmanesh M, Karimi FAH, Akbari E, Rahmani K (2013). The effect of bilayer graphene nanoribbon geometry on schottkybarrier diode performance. Journal of Nanomaterials, 2013.

Ramadan R, Martín-Palma RJ (2020). Electrical Characterization of MIS Schottky Barrier Diodes Based on Nanostructured Porous Silicon and Silver Nanoparticles with Applications in Solar Cells.

Rouger N, Maréchal A (2019). Design of diamond power devices: Application to Schottky barrier diodes. Energies 12(12).

Sato S (2017). Application of graphene to electronic devices. AM-FPD 2017 - 24th International Workshop on Active-Matrix Flatpanel Displays and Devices: TFT Technologies and FPD Materials, Proceedings, 90-93.

Shamsir S, Parvin Poly L, Chakraborty R, Subrina S (2021). Current-voltage model of a graphene nanoribbon p-n junction and Schottky junction diode. IET Circuits Devices and Systems.

Shao Z, Jiang T, Zhang X, Zhang X, Wu X, Xia F, Xiong S, Lee ST, Jie J (2019). Memory phototransistors based on exponential-association photoelectric conversion law. Nature Communications 10(1): 1-10.

Srivastava A, Chakrabarti P (2015). An organic Schottky diode (OSD) based on asilicon/polycarbazole contact. Synthetic Metals 207: 96-101.

Taşçığlu I, Özmen T, Şağban HM, Yağlıoğlu E, Altındal. (2017). Frequency dependent electrical and dielectric properties of Au/P3HT:PCBM:F4-TCNQ/n-Si schottky barrier diode. Journal of Electronic Materials 46(4): 2379-2386.

Tataroğlu A, Altındal Ş, Azizian-Kalandaragh Y (2021). Electrical characterization of Au/nSi (MS) diode with and without graphene-polyvinylpyrrolidone (Gr-PVP) interface layer. Journal of Materials Science: Materials in Electronics 32(3): 3451-3459.

Tozlu C, Mutlu A (2016). Poly(melamine-co-formaldehyde) methylated effect on the interface states of metal/polymer/p-Si Schottky barrier diode. Synthetic Metals 211: 99106.

Wager JF, Keszler DA, Presley RE (2008). Transparent electronics. Transparent Electronics $1-212$.

Wang Y, Yang S, Lambada DR, Shafique S (2020). A graphene-silicon Schottky photodetector with graphene oxide interlayer. Sensors and Actuators A: Physical 314: 112232.

Xie C, Liu CK, Loi HL, Yan F (2020). Perovskite-based phototransistors and hybrid photodetectors. In Advanced Functional Materials 30(20): 1903907).

Ye Y, Gan L, Dai L, Meng H, Wei F, Dai Y, Shi Z, Yu B, Guo X, Qin G (2011). Multicolor graphene nanoribbon/semiconductor nanowire heterojunction light-emitting diodes. Journal of Materials Chemistry 21(32): 11760-11763.

Yenel E, Torlak Y, Kocyigit A, Erden I, Kuş M, Yıldırım M (2021). W- and Mo-based polyoxometalates (POM) as interlayer in $\mathrm{Al} / \mathrm{n}-\mathrm{Si}$ photodiodes. Journal of Materials Science: Materials in Electronics 32(9): 12094-12110. 
Yıldırım M, Kocyigit A, Sarilmaz A, Ozel SS, Kus M, Ozel F (2020). Ternary CuCo2S4 Thiospinel nanocrystal-coated photodiode with improved photoresponsivity and acceptance angles for optoelectronic applications. Journal of Electronic Materials 49(2): 949-958.

Yücedag I, Kaya A, Altındal E, Uslu I (2014). Electrical and dielectric properties and intersection behavior of $\mathrm{G} / \omega-\mathrm{V}$ plots for $\mathrm{Al} / \mathrm{Co}-\mathrm{PVA} / \mathrm{p}-\mathrm{Si}$ (MPS) structures at temperatures below room temperature. Journal of the Korean Physical Society 65(12): 2082-2089.

Zeghdar K, Dehimi L, Pezzimenti F, Megherbi ML, Della Corte FG (2020). Analysis of the electrical characteristics of $\mathrm{Mo} / 4 \mathrm{H}-\mathrm{SiC}$ schottky barrier diodes for temperature-sensing applications. Journal of Electronic Materials 49(2): 1322-1329. 